\title{
MINE TECHNICAL SYSTEM WITH REPEATED GEOTECHNOLOGY WITHIN NEW FRAMES OF SUSTAINABLE DEVELOPMENT OF UNDERGROUND MINING OF CAVED DEPOSITS OF THE ZHEZKAZGAN FIELD
}

\author{
Dossanbay BEKBERGENOV ${ }^{1}$, Gulnar JANGULOVA (102*, \\ Khaini-Kamal KASSYMKANOVA², Bakytbek BEKTUR ${ }^{3}$ \\ ${ }^{1}$ Integrated Development of Colliery Resources, Mining Institute after D. Kunaev, Almaty, Kazakhstan \\ ${ }^{2}$ Department of Cartography and Geoinformatics, Al-Farabi Kazakh National University, Almaty, Kazakhstan \\ ${ }^{3}$ Mining Department, Satpayev University, Almaty, Kazakhstan
}

Received 15 October 2019; accepted 06 December 2020

\begin{abstract}
The article outlines the principles of design of repeated geotechnology at the development of reserves in the conditions of collapsed deposits of the Zhezkazgan field for the purpose of rational management of underground mining processes. This is an integral design principle of the mine technical system with repeated geotechnology, and the foundation for the practice of designing and operation of the subsoil at the development of mineral deposits. At the designing of a mine technical system with repeated geotechnology aimed at the development of collapsed subsoil reserves, the risks and natural and man-made emergencies related to the production are taken into account. Under modern conditions, mining design cannot be employed in isolation from the principles of sustainable development, which implies not only orthodox meaning but also the development that ensures society existence without threatening the needs of future generations. In this connection, the ongoing research incorporates designing of mine technical systems with due account for the principles of sustainable development, which correspond to the current priority direction related to the development of repeated geotechnology within new frames of sustainable development of repeated underground mining of reserves in the conditions of collapsed deposits of the Zhezkazgan field. This contributes to the efficient use of resource-replenishing repeated geotechnology and the possibility of the most complete development of the georesource subsoil potential due to the enhancement of the ore potential at the operation of underground mines of Kazakhmys Corporation Ltd., which is one of the largest copper mining companies in the world.
\end{abstract}

Keywords: geotechnology, collapse, rock mass, underground mining, design and exploitation of mineral resources, mineral deposits, the designing of a mine technical system with repeated geotechnology.

\section{Introduction}

Under modern conditions, mining design cannot be employed in isolation from the principles of sustainable development (Humphreys, 2001; Pimentel et al., 2016; Trubetskoy et al., 2012), which implies not only conventional meaning of this word but also the development that ensures society existence without threatening the needs of future generations.

The sustainable development of ore underground mining means a large-scale set of strategic initiatives of mining production ensuring the operation of each developed field at a non-decreasing growth rate of mining in any period (year, quarter) due to safe, economic, technological, environmental and social efficiency of management, through the use of high adaptive geotechnologies, which will characterize the new technological setup of mining production in the new frameworks of sustainable development of ore underground mining at the initial design stage of the subsoil development and in the period after the mining completion.

The economic development of the Republic of Kazakhstan is largely determined by the operational reliability of the mining and metallurgical complexes, where the issue of sustainable development is promoted at the state level and developed in the largest domestic mining companies that have commercial interest worldwide (Kaplunov, 2014; Bexeitova et al., 2018; Trubestkoy et al., 2006). Relevant

*Corresponding author. E-mail: gulnarzan@gmail.com

Copyright () 2020 The Author(s). Published by Vilnius Gediminas Technical University

This is an Open Access article distributed under the terms of the Creative Commons Attribution License (http://creativecommons.org/licenses/by/4.0/), which permits unrestricted use, distribution, and reproduction in any medium, provided the original author and source are credited. 
studies are being conducted with regard to sustainable development of repeated underground ore mining in the conditions of the caved Annensky area of mining enterprises, at one of the world's largest copper Zhezkazgan deposit. One of the priority directions of further development of Zhezkazgan is the strengthening of the ore potential, an increase in the volume of production of raw materials using open and underground methods.

The long-term development poses a task of involving natural and technogenic reserves of the Zhezkazgan deposit in the development as a result of depletion of relatively high quality mineral resources and increase in the demand for mineral raw materials.

In this regard, currently, repeated development of these reserves is an urgent problem related to the replenishing of the resource potential without additional capital investments and extension of service life at the mining enterprises of Zhezkazgan.

Analysis and opportunity to control the volumes of natural and technogenic georesources involved in the operation at the stage of designing of subsoil development contributes to the achievement of the required level of economic efficiency at lower production rates of recoverable reserves, which ensures the extension of the deposit life cycle, the operating life of the mining enterprise and, in general, expansion of the mineral resource potential of the country (Bekbepgenov, 2013; Head Research Institute of Kazakhmys Corporation Ltd., 2013; Mining Institute after D. A. Kunayev, 2010).

At the same time, the depletion of reserves that are easy to mine under conditions of constant growth in consumption necessitates a new scientific and methodological approach to solving the problems of designing of mining engineering systems with repeated geotechnology that meet the requirements for increasing the completeness and quality of using of natural mineral and technogenic raw materials, industrial areas and relief complicated by geomechanical and geotechnological conditions of the deposits development (Ahanov \& Prokushev, 2010; Bektur et al., 2019).

\section{Materials and methods}

At the consideration of the options for underground repeated mining of ore deposits, it is necessary to note the peculiarity of repeated ore underground mining. This is the fact that mining operations are performed within the mining allotment that has already been disturbed by the primary development. Therefore, old mine workings are used at the opening, preparation and stoping, and that is why these workings must be reconstructed. The use of old haulage ways increases the efficiency of repeated development, however, their reconstruction and restoration may be technically impossible or economically unjustified due to their severe disturbance and distance from the developed reserves. In this case, old workings can be used, for example, for ventilation, and not for haulage.
In the course of repeated development, systems with massive caving of ore and host rocks are widely used (Class VI according to Academician M. I. Agoshkov and Class II according to Prof. V. R. Imenitov) (Agoshkov et al., 1983; Imenitov, 1978).

The methodology of developing a resource-replenishing technology involves solution of technical and economic problems for the substantiation of the optimal parameters of a technological system designed for repeated mining of mineral resources. Its main provisions, principles of research and decision-making should be based on technical and economic laws, and research should be carried out in the following directions:

- Methodological substantiation of the content and structure of rationality of decisions made;

- Geotechnological selection of a method of repeated development of the field or its part; substantiation of the optimal technologies of the underground mining, their application at the researched deposit; justification of process charts and parameters of the preparation and development of individual blocks in the conditions of caved deposits of the copper ore field;

- Feasibility study substantiation of profitability of development, quantitative and qualitative characteristics of the products obtained as a result of the proposed technology of repeated mining of reserves in the conditions of the caved area using the underground method by the example of Zhezkazgan field.

In connection with this, we have identified the main stages of the designing methodology at the development of integrated rational technologies for repeated development of the subsoil:

- Justification and selection of resource-replenishing technology of repeated underground mining, methods of its implementation;

- Development of design methods with the use of GIS modeling of new variants of the technology of repeated underground mining of natural and technogenic reserves in the area of caved deposits.

At the designing of a stoping technology for repeated development of the field as well as for the development of a new field, the following is necessary: knowledge of mining and geological conditions, and the existing mining and technical potential, and taking into account the natural and technogenic factor is one of the most important thing.

Designing the development of reserves located in the zone of the old stoping requires the study of the natural and technogenic factor, the effect of which is evident both its specific presence and in changing the initial properties of the rock mass. Since the repeated development is done on the basis of the existing enterprise with the existing process chart, it is necessary to take into account the capabilities of all its components and to maximize the use of the acquired technological solutions.

At present, mining operations at the enterprises of the Zhezkazgan field with the use of existing technology leads to the formation of significant multi-area outcrops of the 
gob area, the reduction of their stability and, as a result, local or large-scale caving.

According to some references, during the period of development of the Zhezkazgan field, 322.170 thousand $\mathrm{m}^{3}$ of the gob area was formed, about 50 thousand rib pillars and over 520 chain panel and barrier pillars were left.

At the repeated development ore deposits, as a rule, the main cause of caving is the destruction of adjacent pillars in the amount of (according to practice) $7 \div 8$ and $6.500 \div 7.000 \mathrm{~m}^{2}$ roof exposures. At that, the immediate roof is represented by gray sandstones and collapses in large $2 \times 3$ meter blocks $1.5 \div 2.0 \mathrm{~m}$ thick. The sizes of the red rocks are much smaller, which significantly increases the caving height.

The Mining Institute is one of the leading research organizations that study the issue of repeated mining of Zhezkazgan ore deposits, in particular, the issues of repeated geotechnology and geomechanics. As a result of long-term research into the rock mass behavior during the repeated development of ore deposits in various mining and geomechanical conditions, scientists have developed and proposed options for effective repeated development of ore deposits that ensure mining safety with due account for natural conditions of the ore mass occurrence (Temporary methodical guidelines..., 2000; Bekbepgenov, 2012; Chabdarova et al., 1980; Zherebko et al., 2008; Ruppeneit, 1975; Nugmanov et al., 2003; Kazakhmys Corporation Ltd., 2010; Shamganova \& Chabdarova, 2006).

The process of rock caving occurs mainly due to the mining of the ore deposit and the advancement of the mining front or recovery of supporting pillars. The caving process takes quite a long time due to various geotechnical, technological, mining and technical factors. As the stoping front advances, the caved rocks is compacted under the influence of the proper weight (gravity force). As a result, the overlying rocks are cleaved, naturally with appropriate geotechnical properties of the rock mass. At the same time, mine air and humidity most actively influence the destroyed rock mass, forming a multitude of exposed rock planes. What is important is that the cracks are filled with various secondary materials. At a certain stage, the destroyed and loosened rock lumps are moistened through the porosity of the ore and rock masses due to contact with the mine air, and initiate chemical decomposition reactions. All this contributes to the compaction and caking of the caved rock, and the cleavage of the roof of caved rocks leads to its significant increase. In addition, moistening has a significant impact on the strength of rocks, at least this affects the reduction of the strength of gray sandstone within $10 \div 12 \%$. Moistening of siltstone leads to almost $2.0 \div 2.5$ decrease in compressive strength, increasing its volume by $0.3 \div 0.8 \%$. At the same time, the moisture penetration into siltstone reaches a depth of about one meter. As a result, it can be assumed that the siltstone moisture content in an intact mass may be close to limit values.

\section{Result and discussion}

The proposed repeated geotechnology of uncontrolled ore caving in the conditions of a caved area represents the following structure: a $18.6 \mathrm{~m}^{2}$ load-haul drift (height $-4.5 \mathrm{~m}$ and width $4.3 \mathrm{~m}$ ) runs on a $20.0 \mathrm{~m}$ high sublevel at a safe depth $\left(\mathrm{h}_{\mathrm{m}}\right)$ in the rock mass in the stope sill along the strike and along the axis under rooms, which connects $13.8 \mathrm{~m}^{2}$ drilling and loading drives (height $-3.5 \mathrm{~m}$ and width $-4.5 \mathrm{~m}$ ) inclined at an angle of $10-12^{\circ}$ and at an angle of $45^{\circ}$ in the two-way direction to the axis of the load-haul working under each rib pillar. Then, at the end of each drilling and loading drive along the rib pillar axis, funnels are formed on two sides of the load-haul working up to the contact with the inclined soil area of the rib pillar as a result of drilling of fan holes for the funnel and for the complete caving of rib pillars.

Based on the structural elements used for creating the proposed design for the drawing of caved ore from the rib pillar, at the stope sill in the rock mass it is necessary to drive a load-haul working with drives under the rib pillar that can withstand high loads upward from two sides of the load-haul working to form a funnel up to the contact of the sloping part of the soil area with the rib pillar.

The blocks are prepared from the workings of the field horizon by driving load-haul drifts in the underlying rocks at the rib pillar grid (Figure 1).

In the conditions of flat occurrence with overlapping deposits, for repeated development of reserves of destroyed rib pillars with the room full of caved rock, the proposed technology of uncontrolled ore caving in the conditions of the caved area represents the following flow chart (Figure 2).

Load-haul workings (1) run at a safe depth $\left(h_{m}\right)$ in the rock mass in the stope sill under the room (5) located between the rib pillar (6) and continue on both sides of the drive (2) under each rib pillar to their boundary side contacts. Next, the road-heading continues upward from the bottom of the drives forming a funnel (4) as a result of drilling fan holes and pre-splitting to the roof of the rib pillar.

The condition of the roof and sides of all the used workings should be constantly supervised by line personnel. The weakened places in these workings are to be fixed with reinforced concrete lining, concrete, and shotcrete.

It is planned to excavate the pillars from field workings driven in the underlying rocks under the areas of repeated development. The site is prepared and developed in conjunction with the general flow chart of preparation and development of the area in question.

Development includes reserves of isolated, twinned and massive pillars that are not completely destroyed, or their parts located under the mass of caved rocks.

The pillars are broken according to the charts (projects) compiled by the mine in accordance with the uniform safety rules for blasting operations. 


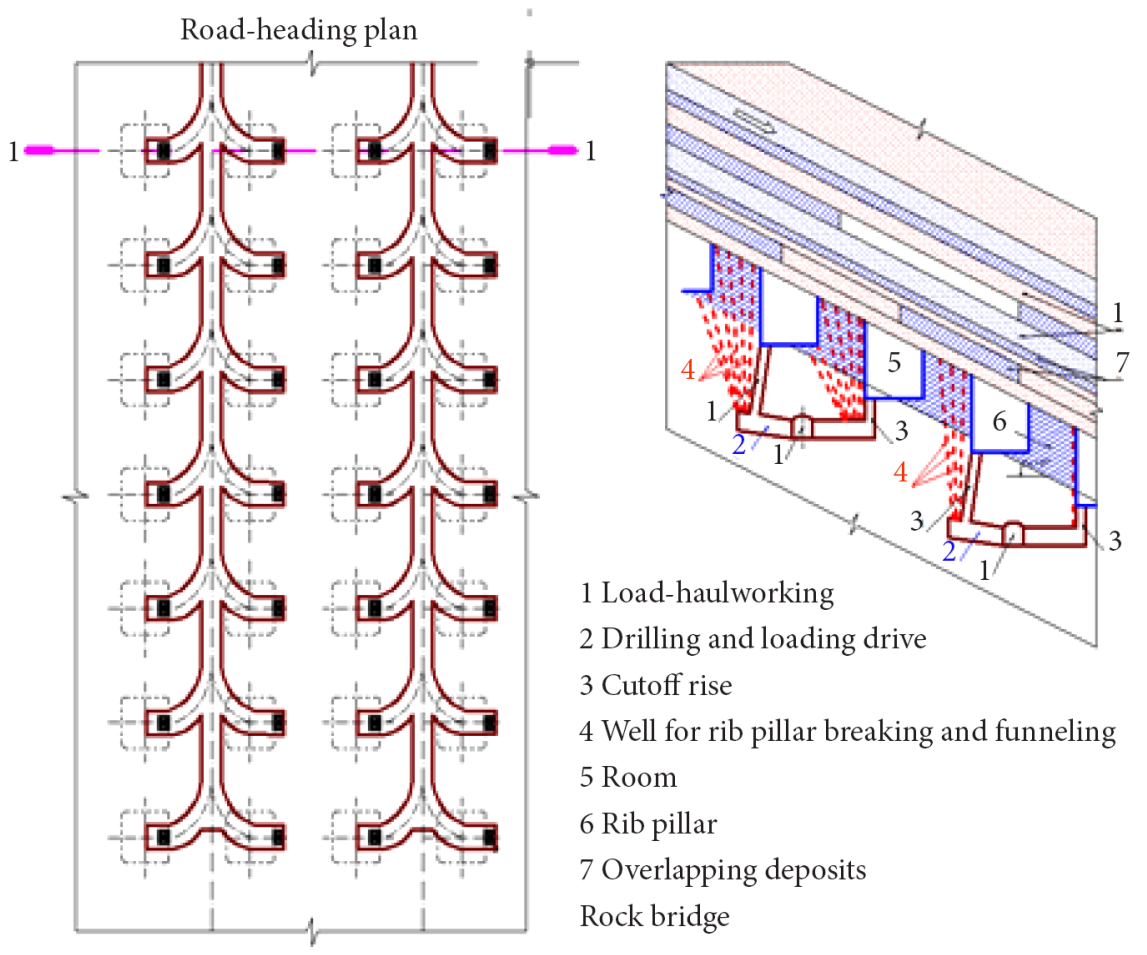

Figure 1. The proposed design of the drawing of caved ore from the rib pillar at the stope sill in the rock mass of inclined overlapping deposits

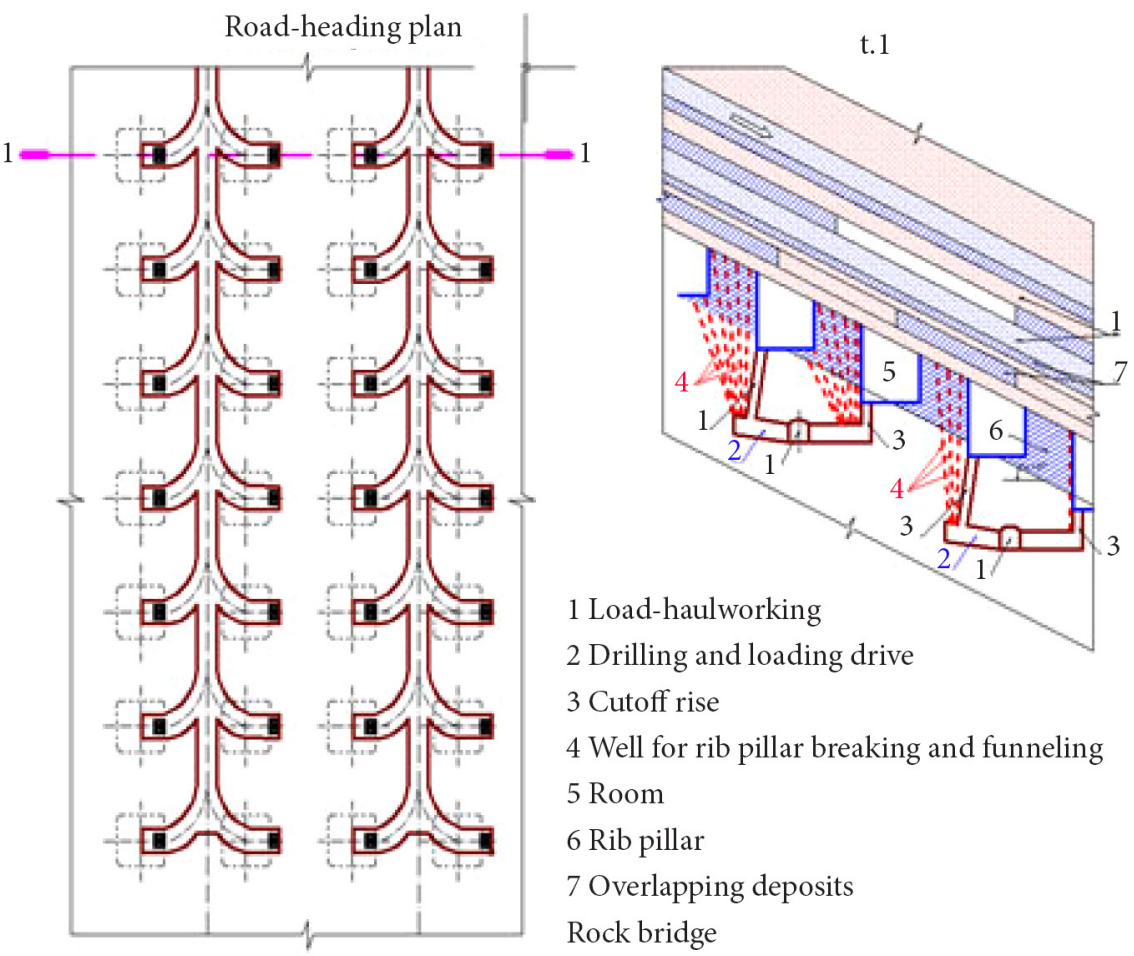

Figure 2. The proposed design of the drawing of caved ore from the rib pillar at the stope $s$ ill in the rock mass of flat overlapping deposits 


\section{Conclusions}

The adopted mining charts ensure the use of a complex of high-performance self-propelled equipment in all technological processes. The stoping includes the sequence of technological processes such as drilling, charging and blasting of wells, airing (during the break between shifts), loading and hauling operations.

The issues of designing of the structural elements of the stope sill for the drawing of ore reserves from caved deposits for the design of the mining and technical system of repeated geotechnology with uncontrolled ore caving suggest solving technical and economic problems to justify the optimal parameters of the technological system in the following directions:

- Methodological substantiation of the content and structure of rationality of decisions made;

- Geotechnological selection of a method of repeated development of the field or its part; substantiation of the optimal technologies of the underground mining, their application at the researched deposit; justification of process charts and parameters of the preparation and development of individual blocks in the conditions of caved deposits of the copper ore field;

- Feasibility study substantiation of profitability of development, quantitative and qualitative characteristics of the products obtained as a result of the proposed technology of repeated mining of reserves in the conditions of the caved area using the underground method by the example of Zhezkazgan field.

All this becomes possible in modern conditions: safe, economic, technological, ecological lyand socially effective management using high adaptive repeated geotechnologies, not so much for mining, but for the purpose of operating each developed area of the subsoil during an indefinite period time, through the initial design of transition stages from one type of geotechnology to another during the deposit mining, as well as for the period after the completion of mining operations. This approach is the essence of a new framework of sustainable development of the repeated mining of the caved deposits of the Zhezkazgan field by means of underground mines of Kazakhmys Corporation Ltd, which is one of the largest copper producer in the world.

\section{References}

Agoshkov, M. I., Boryasov, S. S., \& Boyarskikh, V. A. (1983). Development of ore and non-metallic deposits. Nedra.

Ahanov, T. M., \& Prokushev, G. A. (2010). Mining technology of Zhezkazgan Field, condition and development prospects. Mining Magazine of Kazakhstan, 1, 12-17.

Bekbepgenov, D. K. (2012, October 11-12). On the repeated underground mining technology of uncontrolled ore caving with a high degree of reserves extraction in caved and weakened areas of Zhezkazgan. In Abstracts of the International Scientific and Practical Conference "Mining and Metallurgy in Kazakhstan. Condition and Prospects" Dedicated to the $100^{\text {th }}$
Anniversary of Academician Baikonuvov Omirkhan Aimaganbetovich (pp. 52-55). KazNTU, Almaty.

Bekbepgenov, D. K. (2013). The key issue of repeated development of the remaining reserves of the caved area of the Zhezkazgan Field: Low-cost and effective underground technology. In Problems and Ways of Innovative Development of Mining Industry: Materials of the Sixth International Scientific and Practical Conference (pp. 149-154). Almaty.

Bektur, B. K., Bekbergenov, D. K., Jangulova, G. K., Zherebko, L., \& Seidakhmetova, Zh. (2019). Study of the effect of refining on the sustainability of the level of the system with ore selfminingon the deep levels of the "DNK" colliery. International Journal of Civil Engineering and Technology (IJCIET), 10(1), 2090-2103.

Bexeitova, R., Veselova, L., Kassymkanova, K.-K., Jangulova, G., Baidauletova, G., Zhalgasbekov, Y., Burlibayeva, S., \& Turekhanova, V. (2018). The problem of environmental safety of the fields of mining industrial production of arid zone of Kazakhstan. Geodesy and Cartography, 44(4), 146-155.

https://doi.org/10.3846/gac.2018.4314

Chabdarova, Yu. I., Zhuzhgov, Yu. V., \& Bukin, A. N. (1980). Rock pressure in the anticline structures of Dzheskazgan. Nau$\mathrm{ka}$.

Head Research Institute of Kazakhmys Corporation Ltd. (2013). Feasibility Study "Zhezkazgan Field development master plan": Vol. 6. Preliminary studies and proposals on directions of development and the procedure of underground mining" (Explanatory note P13-19/05).

Humphreys, D. (2001). Sustainable development: Can the mining industry afford it? Resources Policy, 27(1), 1-7. https://doi.org/10.1016/S0301-4207(01)00003-4

Imenitov, V. R. (1978). Underground mining processes at the development of ore deposits. Nedra.

Kaplunov, D. R. (2014). Conditions of sustainable development of the Russia mineral complex. In D. R. Kaplunov, M. V. Rylnikova, \& D. N. Radchenko, Mining Informational and Analytical Bulletin, 10, 3-11.

Kazakhmys Corporation Ltd. (2010). Operating procedure for the development of reserves of the 12bis block of the Ann-3-II deposit of the Annensky Mine. Laboratory of Mining Production, Zhezkazgan.

Mining Institute after D. A. Kunayev. (2010). Methodical guidelines on underground mining of flat and inclined ore deposits of the Zhezkazgan Field, including in the regions adjacent to the weakened and caved areas. Production Association "Zhezkazgantcvetmet” of Kazakhmys Corporation Ltd., Almaty, Zhezkazgan.

Nugmanov, K. Kh., Chabdarova, Yu. I., Bukin, A. N., \& Shamganova, L. S. (2003). Particularities of loads redistribution on rib pillars in the process of their excavation. In Collection of Materials of the International Conference "Geodynamics and Stress Condition of the Subsoil” (pp. 386-392). Novosibirsk.

Pimentel, B. S., Gonzalez, E. S., \& Barbosa, G. N. O. (2016). Decision-support models for sustainable mining networks: Fundamentals and challenges. Journal of Cleaner Production, 112(Part 4), 2145-2157.

https://doi.org/10.1016/j.jclepro.2015.09.023

Ruppeneit, K. V. (1975). Deformability of the fractured rock mass. Nedra.

Shamganova, L. S., \& Chabdarova, Yu. I. (2006). The structural element of the room-and-pillar system. Kazakhstan Industry, 5, 92-94. 
Temporary methodical guidelines on mining in weakened areas of underground mines of the Zhezkazgan field. (2000). Almaty, Zhezkazgan.

Trubestkoy, K. N., Kaplunov, D. R., Rylnikova, M. V., \& Radchenko, D. N. (2006). Problems of integrated development of superlarge fields of strategic raw materials. K. N. Trubestkoy \& D. R. Kaplunov (Eds.). Moscow.

Trubetskoy, K. N., Kaplunov, D. R., \& Rylnikova, M. V. (2012). Development of theoretical foundations of designing and safe operation of mining technical systems based on combined physical-technical and physical-chemical geotechnologies for the development of natural and technogenic solid mineral deposits (pp. 457-469). Research Institute of Comprehensive Exploitation of Mineral Resources of the Russian Academy of Sciences.

Zherebko, L. N., Dzhangulova, G. K., \& Pivovarova, L. M. (2008). Formation of a cave roof in the overlying rock mass represented by layers of different thickness. Scientific and technical support of mining production. Proceedings of the Mining Institute after D. A. Kunaev, 75, 18-21. 